Journal of the Scholarship of Teaching and Learning, Vol. 21, No. 4, December 2021, pp. 187-194. doi: 10.14434/josotl.v21i4.32718

\title{
Witnessing History: Reflections on Teaching in Turbulent Times
}

\author{
Shana Bridges \\ Georgia Southern University
}

\begin{abstract}
Prior political turmoil in the United States constituted a precarious foundation for living and teaching through a pandemic. In this essay, I contend that pandemic separation and ideological distortion have exacerbated polarization and distrust. I also consider the pedagogical implications of rising extremist discourses and conspiratorial thinking for both students and faculty. Educators must pay attention to the rising threat of extremism and consider that our students may be susceptible to radical antidemocratic ideologies as well. To conclude, I provide examples from some of my classes in the communication discipline to illustrate my approach to teaching the complicated intersections of rhetoric and reality in today's polarized political climate.
\end{abstract}

Keywords: pandemic, polarization, pedagogy, extremism, democracy, rhetoric.

The United States was already suffering before the World Health Organization (n.d.) declared COVID-19 a global pandemic on March 13, 2020. The health of American democracy has been deteriorating for some time. When the pandemic began, the nation's political immune system had been weakened by disinformation, acrimony, and distrust. In 2016, The Economist Intelligence Unit (2016) downgraded the United States from a "full democracy" to a "flawed democracy" on their Democratic Index. They cited a "long-term trend of declining popular trust in government, elected representatives, and political parties" (p. 3). The pandemic has only exacerbated political tensions that were already present in this country before COVID-19 spread from shore to shore.

Educators have a unique viewpoint for the pandemic. Considered frontline workers, teachers at many schools ( $\mathrm{K}-12$ through college) have been face-to-face with students in the classroom. Others have struggled for face time with their students online. No matter the modality, we are all faced with the challenge of teaching students through a pandemic. Educators have pivoted, created online content, learned to Zoom, battled Wi-Fi issues, taught in masks, and taught to black Zoom boxes. We have also shown compassion to students, even while working through personal loss and struggles and an increased workload. The pandemic has made everything harder, teaching included.

Educators have the Sisyphean task of helping students make sense of the world. That becomes more difficult in such turbulent times as these. It is no small feat to continue teaching while living through your first pandemic and bearing witness to social unrest and a violent attempted insurrection. As a communication professor who studies political rhetoric and teaches classes ranging from Public Speaking to Rhetorical Criticism, I have always emphasized that rhetoric creates reality. I promote the ethical use of language and critical consideration of public messages. I encourage pluralistic discourses in the classroom. I try to help the students understand that the current rhetorical and political climate is constituted by prior discourses and events. I have encouraged students to pay attention to the messages circulating and recognize that rhetorical constructions influence our worldview. This pedagogical approach is more complicated in a posttruth world of disinformation, anti-intellectual sentiment, and conspiratorial thinking.

In this essay, I reflect on how pandemic separation and ideological distortion have exacerbated polarization and distrust and prolonged the pandemic in this country. I also consider the pedagogical implications of rising extremist discourses and conspiratorial thinking for both students and faculty. Educators must pay attention to the rising threat of extremism and consider that our students may be susceptible to radical antidemocratic ideologies as well. To conclude, I provide examples from some 
of my classes in the communication discipline to illustrate my approach to teaching the complicated intersections of rhetoric and reality in today's polarized political climate.

\section{Pandemic Separation and Political Distortion}

To slow the spread of the highly contagious coronavirus, countries around the world imposed nationwide lockdowns to keep people from gathering in groups. In the United States, individual states regulated their own pandemic closures. People were encouraged to stay isolated in their homes. Businesses across the country shut down, and unemployment soared to 14.8\% in April 2020 (Falk et al., 2021, p. 2). Out of necessity, K-12 schools and universities sent students home and shifted to a remote online format. American citizens remained separated from each other for months on end.

In quarantine, people turned to their screens for information and entertainment. Google, YouTube, and social media algorithms funneled users toward more extremist content (Whittaker et al., 2021). People fell down conspiracy-theory rabbit holes looking for answers. Psychological studies revealed a general decline in mental health and a strong correlation between pandemic stress and paranoia (Kowalski et al., 2020; Maekelae et al., 2021; Zhang et al., 2020). The more people engaged online, the more they participated in echo chambers that often perpetuated misinformation and disinformation. The news outlet citizens chose influenced their views of events such as George Floyd's murder and subsequent Black Lives Matter protests. Partisan pundits distorted public health messages and dismissed and stigmatized the Centers for Disease Control and Prevention's advisories to wear masks and get vaccinated. The lives of U.S. citizens abiding by pandemic restrictions got smaller and more insular. For those citizens who already adhered to an antigovernment worldview, the year of pandemic-related limits reinforced their disdain for government overreach. Destructive emotions such as anger, fear, and resentment had ample time to fester as American minds wandered in quarantine isolation.

The internet has complicated John Stuart Mill's idealized metaphor of democracy as a marketplace of ideas because the marketplace includes unverified information circulating in partisan and extremist echo chambers. According to Farrow and Moe (2019), "The Internet facilitated a process by which like-minded individuals could find each other, communicate, and organize" (p. 273) and social media "made it easier to have erroneous beliefs reinforced by social recognition" (p. 273). Unchecked inflammatory discourses have painted fellow citizens in nefarious terms and have perpetuated distrust that is highly detrimental to democracy.

\section{The Rise of Extremism and Implications for Educators}

Unfortunately, hyperpartisanship and political brinkmanship have constituted the climate of American politics since the 1980s. The tragic events of September 11, 2001 ushered in an era of fear mongering, domestic surveillance, unpopular wars, and an overall decline in American influence abroad. Former president Donald Trump did not cause the trust deficit, but "he was the beneficiary of it" (The Economist Intelligence Unit, 2016, p. 4). His lack of political experience appealed to anti-establishment voters who desired a "break from the status quo" (p. 12). In office, the former president often derided democratic institutions including the free press, judiciary, and bureaucracy (Lieberman et al., 2018, p. 470). His move to discredit the election results and refusal to engage in a peaceful transfer of power after the 2020 election further eroded public trust (Bermeo, 2016; Norris, 2021). The attempted insurrection by Trump supporters on January 6, 2021 showed just how destructive distrust and misinformation are for democracy.

College and university faculty need to be realists about the reach of extreme ideas. January 6th showed us that a significant number of people wholeheartedly believed the lie of a fraudulent election

Journal of the Scholarship of Teaching and Learning, Vol. 21, No. 4, December 2021. josotl.indiana.edu 
and were willing to disrupt the official Congressional election certification to try to keep Donald Trump in power. A May 2021 Reuters/Ipsos poll (Reuters, 2021) showed that 61\% of Republicans still thought the election was "stolen" from Trump. Only $29 \%$ of Republicans believed he should be held responsible for the January 6th Capitol riots, and 25\% of all Americans (including 53\% of Republicans) believed that Trump was the "true president." We had a year of physical separation-in our homes, by masks, by the 6-ft distance encouraged for safety. January 6th revealed just how separated we had become as a nation.

The events of January 6,2021, were the culmination of years of increasingly illiberal, antiestablishment, extremist discourses and marked a major turning point in our nation's history. A matrix of social and political conditions constituted a contentious climate of acrimony and distrust and heralded an uncertain political future for a country that had always taken democracy for granted. Antidemocratic tropes are often communicated in entertaining forms such as memes and discussion boards. Millions of people consume content curated for them using algorithms. With each video response or mouse click, the algorithms learn about the users and appeal to them using previous online choices for future content suggestions. Social media sites such as Facebook, YouTube, and Twitter have provided increasingly divisive content to encourage more site engagement (Barrett et al., 2021). It is imperative for college and university faculty to recognize that a complex, entangled culture of discourses exists that many of us are not aware of or plugged into.

Fellow educators, no matter what you think about QAnon and other alt-right groups and ideologies, they are gaining traction in a large section of the population, and we cannot ignore the possibility that some of the theories may appeal to students on either the Left or the Right. A recent poll indicated that 15\% of the U.S. population aligns with support the QAnon movement (Public Religion Research Institute, 2021). This is about 30 million people, equivalent to the number of White Evangelical protestants or White mainline protestants (PRRI, 2021). Alt-right and militia groups can be violent, as we saw on January 6. According to data from the Center for Strategic and International Studies, domestic terrorist attacks have increased to their highest level in 25 years, and right-wing extremist groups are responsible for most of the violence (O’Harrow, Jr. et al., 2021).

Because they are antiestablishment and antiliberalism, QAnon and other alt-right groups dismiss Progressive goals of social justice, equal rights, civil rights, tolerance, inclusion, pluralism, and diversity. These issues are also the subjects of pedagogical theory and curriculum in higher education. Many a college professor has discussed one or more of these issues as part of their approach to student/citizen learning and development. QAnon adherents are just some of the people who have decried discussions of privilege, critical race theory, and feminism as divisive concepts that demonize White people and threaten majority dominance. It is common for Republicans to accuse universities of supporting liberal indoctrination, citing curriculum and comments from professors. What one person may see as a righteous attempt to cultivate thoughtful and empathetic citizens, an alt-right extremist might interpret as a threat to their current and future rights and power.

We must consider the fact that there have been and will be more than a few of our students who endorse alt-right ideas. They may even have animosity toward the academy because of their worldview. Even if many students do not know about the various movements or adhere to antipluralistic ideologies, it is still important for educators to be aware that extremist ideas have garnered a more mainstream following. Extremist sentiments will no doubt enter the classroom wrapped in the First Amendment, and educators should be prepared for more antiauthority pushback from students. In the next section, I discuss the pedagogical methods I implement to address the challenges of distrust, disinformation, and division in the current moment.

Even if you are not in the field of communication, these ideas are still useful for teaching students in these polarizing times. The link between rhetoric and reality is more apparent than ever. If rhetoric is a big reason for our current political crises, then it stands to reason that rhetoric could

Journal of the Scholarship of Teaching and Learning, Vol. 21, No. 4, December 2021. josotl.indiana.edu 
also be a solution. I encourage students to unpack the language they encounter before endorsing an idea. I also encourage them to think carefully about the language they use to communicate to and about others. An informed citizenry and a more robust democracy are possible, but we must see each other in terms of our shared humanity. The move toward more productive democratic deliberation depends, in part, on the language used to characterize individuals, groups, and issues. In other words, we must be more critical consumers of information that encourages us to see our differences as unreconcilable.

\section{Teaching in Turbulent Times}

The exponential number of COVID deaths-including people close to me-coupled with the acrimony of the election and subsequent contested results and the destructive myth of a rigged election had a drastic impact on my outlook. Much of what I taught began to seem pointless. People were dying left and right from a highly communicable novel virus. We were a nation potentially facing the demise of its storied democracy. Who cared about speech outlines or APA formatting? It was difficult to push forward when the world was turned upside down. It was also difficult to assure my students in the face of such uncertainty. This was my first pandemic, too. I was also worried about the future of our democracy, considering the rampant polarization that had been exacerbated during Trump's term in office. I started to doubt my own ability to teach my students anything significant enough to help them become more thoughtful citizens. After all, what they were exposed to in class was only a fraction of the information they encountered on any given day.

To assuage my own distress and paralysis, I decided the best way I could contribute to improving political relations was to put more emphasis on media literacy in all my classes. Media literacy has become a buzzword, but the embodied practice involves developing critical thinking skills and competence "for understanding media messages, for conscious choice of appropriate media channels and media products, and for self-aware consumption of media focused on enhancing sensitivity [and] reasoning" (Plencner, 2014, p. 7).

As I mentioned earlier, the idea that rhetoric creates reality permeates the courses I teach. In Public Speaking, I balance between teaching students the principles of public speaking and encouraging them to see speech as a highly ethical endeavor, since what we say can influence the worldviews of others. Students learn how to find credible sources of information as opposed to speculative, conspiratorial, and unsupported evidence. Nevertheless, in the last few years, I have had more requests to give speeches on conspiracy theories than ever before. The unknown appeals to the students, and because of this, we talk about fallacies such as the ad ignorantiam fallacy (also called the appeal to ignorance) that asserts a proposition is true if it has not yet been proven false or false if it has not been proven true. Elana Michelson (2019) suggested that we encourage students to "account for their epistemic practices, for the ways in which they process evidence ... [and] adjudicate truth claims" (p. 153):

What makes a source trustworthy? What kinds of background knowledge are required to make a credible truth claim? How does one evaluate the value of a piece of evidence? How do we distinguish between purported information, including information that we would like to believe, and information that we are justified in believing is true? (p. 153)

These are similar to questions posed in the process of critical thinking, but these go further to encourage students to interrogate their own methods for testing the ethics and determining the viability of various messages.

Journal of the Scholarship of Teaching and Learning, Vol. 21, No. 4, December 2021. josotl.indiana.edu 
In Communication Research, my version of a media literacy curriculum involves having students read and discuss journal articles that focus on the relationship between language and reality. Three articles were especially useful for helping students conceptualize the power of language in such tumultuous times. The authors provide useful perspectives on the power of repetition, metaphors, and emotion in public discourses. I emphasize that rhetoric should be ethical, but it can be used to generate, weaponize, and capitalize on fear, paranoia, anger, and outrage. I have used these articles for several semesters now, but they took on new meaning after the insurrection.

I always begin with Steven Perry's (1983) “Infestation Metaphor in Hitler's Rhetoric" because it helps students understand the power of metaphor in political rhetoric. Perry shows how Hitler's language characterized German Jews and other minorities as an infestation of the German national body. Through repeated scapegoating and dehumanization, Hitler managed to instill fear and paranoia and constituted a moral carte blanche for the Holocaust (Perry, 1983, p. 234). The article offers the startling conclusion that metaphors have enough power for one man to gain tacit approval for genocide.

In our class discussion, I provide contemporary examples of dehumanizing language/metaphors used to encourage people to endorse prejudiced views that minority groups pose a threat to national well-being. A prime example is former President Trump's repeated recitation of "The Snake," a poem about a woman who takes in a snake to nurse it to health and is later fatally bitten. The woman is shamed by the snake. "'Oh shut up, silly woman,' said the reptile with a grin. You knew damn well I was a snake before you took me in" (Taddonio, 2019). Trump used the snake metaphor to poetically dehumanize immigrants and discourage support for such policies as chain migration. I use this example to help students recognize the link between historical and contemporary rhetoric: Persuasion can occur incrementally over time if discourses are repeated often enough. Beginning during the pandemic semesters, I used the "Big Lie" that the election was stolen by Democrats as another example of how repetition can be effective. Students have been responsive to Perry's article because he illustrates the potency of language, and the contemporary examples help them recognize that we must remain vigilant and continue to reject discourses that encourage dehumanization and distrust.

Jessica Johnson's (2018) examination of how White men have been radicalized online begins with \#PizzaGate, a debunked conspiracy theory alleging that Hillary Clinton ran a global child sex trafficking ring from the basement of the Comet Ping Pong Pizzeria in Washington, D.C. Armed with guns and ammo, Edgar Madison Welch drove from North Carolina to Washington, D.C. to investigate the pizzeria. He threatened the owners and fired his gun inside the establishment, believing the door he shot led to the basement where members of the cabal met. In fact, it was a server's cabinet; the restaurant did not have a basement (Johnson, 2018, p. 100). Welch's vigilante investigation of this supposed child sex trafficking ring was the precursor to the QAnon movement (Hayden, 2021).

Johnson's (2018) conclusion is that right-wing extremists are radicalized online through an affective network of conspiracy theory websites and social media. Disinformation via fake news circulates and invokes feelings of paranoia, fear, resentment, outrage, and hate. Influential right-wing figures such as radio host Alex Jones capitalized on these emotions by selling products to assuage anxieties that are provoked by conspiracy theories. For example, to prevent the "feminization of men" through drinking water, Jones sold drinking straws and bone broth (Johnson, 2018, p. 112). Johnson's article is helpful for understanding how emotions are manipulated through online conspiracy theories. I couple this with the next article, which provides vocabulary for media literacy concepts.

Alex Plencner's (2014) discussion of critical thinking and the challenges posed by the internet offers a helpful guide for how to evaluate internet sources. As I have mentioned, the internet complicates democracy because citizens do not draw from the same wells of information, and much of the information is inaccurate, speculative, or unverifiable. Plencner wrote:

Journal of the Scholarship of Teaching and Learning, Vol. 21, No. 4, December 2021. josotl.indiana.edu 
Virtual worlds of cyberspace offered an illusion of control and reduction of harm. Internet users could gain false sense of reliability of online information due to its confirmation by social relevance, its significance to other people. Facts were no more facts but rather factoids notions and suggestions validated according to emotional logic of the user and to [their] wishful thinking. Evidence was no more necessary. (p. 6)

Media literacy involves critical thinking as well as the recognition of the psychological aspect of persuasion. "Knowing one's own incompetence is a starting point for acquiring self-awareness and freedom of thinking" (p. 6). Media-literate individuals have better skills for navigating the posttruth internet landscape.

People who are media literate recognize that some beliefs may be the result of selective thinking known as "confirmation bias" (Plencner, 2014, p. 7). Plencner (2014) contended that "we tend to believe what we want to believe and rely on superficial information that resonates with our already held views" (p. 7). Illiterate citizens often ignore contrary information that serves as a source of cognitive dissonance. They are also more likely to give into false arguments that exhibit fallacies such as fear appeals and wishful thinking (p. 7). Plencner highlighted the concept of the DunningKruger effect: "The incompetent have a tendency to overestimate their capabilities, they are incompetent to evaluate the competence level of others, and they are not willing to admit it" (p. 9). Critical thinking "does not mean thinking negatively, being full of prejudices towards others who hold different opinions" and does not exclude emotions since they have a place in judgment (p. 8). Thinking critically means acknowledging that bias plays in content production and consumption. Plencner encouraged people to approach the pursuit of truth with a sense of "intellectual humility," to be aware of our own limits as biased human beings (p. 10).

Plencner (2014) discussed the allure of conspiracy theories that provide alternative interpretations of events. "Behind disparate conspiracies there is the conviction that powerful, hidden, evil forces control human destinies" (p. 11). Conspiracy theories are often endorsed to make sense of the world, but they also contribute to "paranoid thinking" and result in "a worldview characterized by a sharp division between the realms of good and evil" (p. 11). Plencner argued that paranoid thinking is related to high levels of anxiety and is more prevalent in people who exhibit "insecure attachment styles" and experience high levels of distrust of authority figures (p. 13). In a helpful conclusion, he provided a "pyramid of credibility" to guide students in their critical thinking. Plencner said peerreviewed publications are the gold standard in this hierarchy. Lower tiers include quality media (e.g., reputable newspapers), blogs and social media, and hearsay, respectively. Plencner reminded us that uncritical people may be more persuaded to change their beliefs if empathy (instead of strife) is at the forefront of a discussion on various issues.

I still wrestle with how to address our current political crises. In the past, I have dismissed hopes for a healthier democracy as Pollyannish. January 6th felt like a rupture. Learning more about extremist views and how they are increasing their reach served as a wake-up call. I still feel uncertain about the future, but my hope is that our nation can heal as our economy heals and COVID-19 is defanged (though the virus is not going away anytime soon). I am grateful to have made it to the vaccine without catching the virus; I know many others were not as lucky. Teaching through a pandemic has been about putting one foot in front of the other, showing compassion to our students and ourselves, and trying to avoid illness. Faculty members across the country adapted their classes and put in a lot of long hours and hard work to facilitate student learning in dynamic circumstances. Teaching during a pandemic is difficult for reasons I have previously stated. Teaching during a pandemic and after an insurrection is one of the most difficult things many of us have ever had to do.

Journal of the Scholarship of Teaching and Learning, Vol. 21, No. 4, December 2021. josotl.indiana.edu 


\section{Conclusion}

We are teaching in "liquid times," said Green and Gary (2016). Tectonic shifts in thought are underway. "The foundational or originary assumptions of the modern university no longer match the subjectivities of its students" or the dynamics of turbulent politics (Green \& Gary, 2016, p. 53). Professors will have to continue to be adaptable to changing conditions and aware of our limited knowledge about particular topics. We must also work to cultivate trust among students and professors to deter more extremist discourses from taking root. For those educators who were in the classroom, being face-to-face for the 2020-2021 school year was not always easy, but it meant that we could be with each other in the same space. Being together can help us develop a more empathetic sensibility toward others. Being apart has been one of the most difficult aspects of virtual teaching and learning. In these turbulent times, my primary message in the classroom has been to recognize the role rhetoric plays in creating our view of our fellow citizen and the world writ large. Only when we sharpen our critical thinking skills and stop seeing each other as an enemy can we fortify our fragile democracy.

\section{References}

Barrett, P., Hendrix, J., \& Sims, G. (2021, September). How tech platforms fuel U.S. political polarization and what government can do about it. Brookings Institute Techtank.

https://www.brookings.edu/blog/techtank/2021/09/27/how-tech-platforms-fuel-u-spolitical-polarization-and-what-government-can-do-about-it/

Bermeo, N. (2016). On democratic backsliding. Journal of Democracy, 27(1), 5-19. https:// doi.org/10.1353/jod.2016.0012

The Economist Intelligence Unit. (2016). Democracy index 2016: "Revenge of the deplorables." https://www.eiu.com/public/topical_report.aspx?campaignid=DemocracyIndex2016

Falk, G., Romero, P. D., Nicchitta, I.A., \& Nyhof, E. C. (2021, August). Unemployment rates during the COVID-19 pandemic. Congressional Research Service. https://sgp.fas.org/crs/misc/R46554.pdf

Farrow, R., \& Moe, R. (2019). Rethinking the role of the academy: Cognitive authority in the age of post-truth. Teaching in Higher Education, 24(3), 272-287. https://doi.org/10.1080/13562517.2018.1558198

Green, L., \& Gary, K. (2016). Pedagogy for a liquid time. Studies in Philosophy and Education, 35, 4762. https://doi.org/10.1007/s11217-015-9470-7

Hayden, M. E. (2021, July). There's nothing you can do: The legacy of \#pizzagate. Southern Poverty Law Center. https://www.splcenter.org/hatewatch/2021/07/07/theres-nothing-you-can-dolegacy-pizzagate

Johnson, J. (2018). The self-radicalization of white men: "Fake news" and the affective networking of paranoia. Communication Culture \& Critique, 11(1), 100-115.

https://doi.org/10.1093/ccc/tcx014

Kowalski, J., Marchlewska, M., Molenda, Z., Gorska, P., \& Gaweda, L. (2020). Adherence to safety and self-isolation guidelines, conspiracy and paranoia-like beliefs during COVID-19 pandemic in Poland-Associations and moderators. Psychiatry Research, 294, Article 113540. https://doi.org/10.1016/i.psychres.2020.113540

Lieberman, R. C., Mettler, S., Pepinsky, T. B., Roberts, K. M., \& Vallely, R. (2018). The Trump presidency and American democracy: A historical and comparative analysis. Perspectives on Politics, 17(2), 470-479. https://doi.org/10.1017/S1537492718003286 
Maekelae, M. J., Reggev, N., Defilipe, R. P., Dutra, N., Tamayo, R., Klevjer, K., \& Pfuhl, G. (2021). Identifying resilience factors of distress and paranoia during the COVID-19 outbreak in five countries. Frontiers in Psychology, 10. https://doi.org/10.3389/fpsyg.2021.661149

Michelson, E. (2019). The ethical knower: Rethinking our pedagogy in the age of Trump. Adult Education Forum, 69(2), 142-156. https://doi.org/10.1177/0741713619834626

Norris, P. (2021, January 7). It happened in America: Democratic backsliding shouldn't have come as a surprise. Foreign Affairs. https://tinyurl.com/sscwhdn5

O’Harrow, Jr., R., Tran, A. B., Hawkins, D. (2021, April). The rise of domestic extremism in America. The Washington Post. https://wapo.st/3DA41md

Perry, S. (1983). Rhetorical functions of the infestation metaphor in Hitler's rhetoric. Southern Communication Journal, 34(4), 229-235. https:// doi.org/10.1080/10510978309368147

Plencner, A. (2014). Critical thinking and the challenges of the internet. Communication Today, 5(2),418.

Public Religion Research Institute. (2021, May 27). Understanding QAnon's connection to American politics, religion, and media consumption. https:// tinyurl.com/4ff3fkwv

Reuters. (2021, May 24). 53\% of Republicans view Trump as true U.S. president-Reuters/Ipsos. https:// tinyurl.com/vumrr9cc

Taddonio, P. (2019, October 17). Watch: Donald Trump and "The Snake." Frontline. https://tinyurl.com/47i2y6bv

Whittaker, J., Looney, S., Reed, A., \& Votta, F. (2021). Recommender systems and the amplification of extremist content. Internet Policy Review, 10(2). https:// doi.org/10.14763/2021.2.1565 World Health Organization. (n.d.). Timeline: WHO's COVID-19 response. https:// tinyurl.com/4c4urn24

Zhang, J., Lu, H., Zeng, H., Zhang, S., Du, Q., Jiang, T., \& Du, B. (2020). The differential psychological distress of populations affected by the COVID-19 pandemic. Brain, Behavior, and Immunity, 87, 49-50. https://doi.org/10.1016/j.bbi.2020.04.031 